\title{
Genus-specific leptospiral antigen and its possible use in laboratory diagnosis
}

\author{
A. PALit AND J. GULASEKHARAM \\ From the Commonwealth Serum Laboratories, Parkville, Victoria, Australia
}

SYNOPSIS Sheep red cells, sensitized with a genus-specific leptospiral substance extracted from a water leptospira, were preserved by freeze drying. The serological reactivity of the preparation was tested against a total of 41 sera from proven cases of human leptospirosis and 27 from proven cases of animal leptospirosis. The sensitized, freeze-dried red cells appeared to be a sensitive reagent for the detection of leptospiral antibodies by haemagglutination. The use of this reagent as a screening test for leptospiral diagnosis is discussed. In the reported haemagglutination test on human and rabbit antisera the findings suggested that only IgM (19S) antibodies took part in the reaction.

The diagnosis of leptospiral infections in man and animals may be established either by isolating the organisms or by detection of specific antibodies. Generally speaking, isolation of leptospires from infected man and animals is time-consuming and beyond the scope of most diagnostic laboratories. Undoubtedly, the isolation of the infecting strain is the most desirable method to diagnose the infection but this depends on the stage of illness, type of material collected, availability of suitable medium (Ellinghausen and McCullough, 1965), and laboratory facilities for handling animals. On the other hand, detection of specific leptospiral antibodies is a relatively easy and more convenient procedure.

Among the serological tests the microscopic agglutination test using live (or killed) leptospires as antigens is the standard reference test for leptospiral diagnosis (World Health Organization, 1967). However, as a screening test the microscopic agglutination test suffers from certain disadvantages (World Health Organization, 1967), eg, cultures of a large number of serotypes have to be maintained, it involves the handling of live organisms, and it is also time-consuming, particularly when large numbers of sera need to be tested. This investigation was initiated to develop a suitable stable reagent for the routine screening of suspected serum samples by diagnostic laboratories. It is an extension of the work of Chang and McComb (1954) and Cox, Alexander, and Murphy (1957) who demonstrated that a particular leptospiral extract behaved like a genus-specific antigen in detecting antibodies against

Received for publication 24 October 1972. homologous serotypes of leptospires. An attempt was also made to determine the type of serum immunoglobulins taking part in the genus-specific haemagglutination test. Such information might give an indication regarding the applicability of the test in the various stages, eg, acute, chronic, and convalescent, of the illness.

\section{Materials and Methods}

GROWTH OF LEPTOSPIRES AND ANTIGEN EXTRACTION

The strain of Leptospira used to prepare antigen was Patoc 1 (Biflexa complex, Semaranga serogroup, serotype patoc): this was obtained through the courtesy of the Laboratory of Microbiology and Pathology, Department of Health, Brisbane, Queensland (WHO Leptospira Reference Laboratory). The organisms were grown in 8-10 litre volumes in a modified Korthof's medium (Alston and Broom, 1958) supplemented with $10 \%$ sheep serum derivatives (Faine, 1969). The inoculated medium was incubated for seven to 10 days at $30^{\circ} \mathrm{C}$ after which the cells (approximately $10^{8}-2 \times 10^{8}$ cells $/ \mathrm{ml}$ ) were harvested by continuous-flow centrifugation at $14000 \mathrm{~g}$ in a refrigerated centrifuge at $4^{\circ} \mathrm{C}$. The pellets were suspended in phosphate-buffered saline (PBS), pH 7.2 (Carpenter, 1965), washed twice, and resuspended in the same buffer in $8-10 \mathrm{ml}$ volumes. Antigen was extracted from the washed organisms by the method of Chang and McComb (1954) with some minor modifications. At the end of the $50 \%$ ethanol precipitation stage, the mixture was centrifuged at $10000 \mathrm{~g}$ for 20 minutes. To the supernatent 
sufficient ethanol was added to bring the concentration up to $90 \%(\mathrm{v} / \mathrm{v})$ and this was stored overnight at $4{ }^{\circ} \mathrm{C}$. The precipitate which appeared was separated and suspended in PBS. This antigen suspension was stored at $-20 \mathrm{C}$.

\section{ANTISERA}

All the antisera were obtained in the freeze-dried form from Difco Laboratories (Detroit, Michigan, USA) except the Patoc 1 antiserum and the antiserum against the ethanol precipitated Patoc 1 antigen. The Patoc 1 antiserum was produced by injecting intravenously $5 \mathrm{ml}$ of a 5-7-day-old culture (grown in Korthof's medium supplemented with $10 \%$ rabbit serum) into each of three rabbits. Four such injections were given at an interval of four to five days. These rabbits had no haemagglutination or microscopic-agglutinating antibodies when tested before immunization. The rabbits were bled by cardiac puncture on the seventh day after the last injection. Antiserum against the ethanol-precipitated antigen was produced by injecting a single dose of $0.25 \mathrm{ml}$ of the antigen suspension intravenously into each rabbit. These rabbits were bled at intervals of $0,4,10,14,22$, and 30 days by cardiac puncture. The serum samples were distributed into small aliquots and stored at $-20^{\circ} \mathrm{C}$.

Bovine and human serum samples from proven cases of leptospirosis were obtained through the courtesy of Mr N. D. Stallman, WHO Leptospira Reference Laboratory, Brisbane. All the serum samples employed in the haemagglutination test were inactivated by heating at $56^{\circ} \mathrm{C}$ for 30 minutes and then absorbed with one fifth volume of washed, packed, sheep red cells. No history was available as to the stage of the disease when the sera were collected.

Goat antisera to human IgA and IgM were obtained from Hyland Laboratories, Los Angeles, California, USA

SENSITIZATION OF FRESH SHEEP RED CELLS FOR HAEMAGGLUTINATION TEST

Sheep red cells preserved in Alsever's solution were washed three times in PBS. A $10 \%$ suspension of these cells was prepared from the packed red cells in the same buffer. Packing of the washed red cells was done by centrifuging the cell suspension at $1500 \mathrm{~g}$ for 10 minutes. To $1 \mathrm{ml}$ of the optimum dilution (see $\mathrm{HA}$ test described below) of the antigen, $0.1 \mathrm{ml}$ of the $10 \%$ red cell suspension was added and the mixture allowed to react at $37^{\circ} \mathrm{C}$ with intermittent shaking. At the end of one hour the cells were washed twice and a $1 \%$ sensitized red cell suspension prepared in the above mentioned buffer. These sensitized cells were used in the HA test.

INDIRECT HAEMAGGLUTINATION (HA) TEST The indirect haemagglutination (HA) test was performed essentially as described by Chang and McComb (1954) and Palit and Sharma (1971). The optimum dilution of antigen required for maximum sensitization of the red cells for the HA test was determined by the conventional checker board titration (Table I). A serial two-fold dilution $\left(\log _{2}\right)$ of the antiserum was made up in PBS containing $1: 200$ normal rabbit serum as stabilizer. Similar dilutions of the antigen suspension were also prepared in the same buffer. The method for sensitization of fresh sheep red cells is described above. The HA test was performed in $U$ bottom Perspex plates using 4 volumes of diluted serum and 1 volume of $1 \%$ sensitized red cells. The antigenantibody mixture was allowed to react at $37^{\circ} \mathrm{C}$ for one hour and the results were recorded after overnight storage of the plates at room temperature. The optimum dilution of the antigen required for sensitization was that dilution which (when coated onto red cells) showed haemagglutination with the highest dilution of the homologous antiserum. In the final test the sheep red cells were sensitized with the predetermined optimum dilution of the antigen and then reacted with the test serum samples for determination of antibody titres. The highest dilution of serum showing haemagglutination was considered as the end titre of the serum. Necessary serum and antigen controls were also set up with the test.

\begin{tabular}{|c|c|c|c|c|c|c|c|c|}
\hline \multirow[t]{2}{*}{ Antigen Dilutions } & \multicolumn{8}{|c|}{ Antiserum (Homologous) Dilutions } \\
\hline & 8 & 16 & 32 & 64 & 128 & 256 & 512 & 1024 \\
\hline $1: 8$ & $\therefore$ & $\rightarrow$ & $\therefore$ & $\dot{-}$ & -.- & 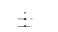 & - & - \\
\hline $1: 16$ & $\therefore$ & - & - & - & $\cdots$ & $=$ & - & - \\
\hline $1: 32$ & $\therefore$ &.- & - & $\ldots$ & .. & 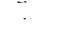 & & - \\
\hline $1: 64$ & - & $\cdots$ & - & - & -- & & - & - \\
\hline $1: 128$ & . & & - & & & & - & - \\
\hline $1: 256$ & - & .. & + & $\cdots$ & - & - & - & - \\
\hline
\end{tabular}

Table I Determination of optimum dilution of antigen for sensitization of sheep erythrocytes

+ positive haemagglutination

\pm doubtful haemagglutination

- negative haemagglutination 
PREPARATION OF SENSITIZED, PRESERVED SHEEP RED CELLS

\section{Pre-treatment of red cells with formalin}

Fresh sheep cells were formalinized according to the method of Daniel and Stavitsky (1964) and stored at $4^{\circ} \mathrm{C}$. These cells were then subjected to further treatment:

(a) From the above cells 1 and $2.5 \%$ suspensions were prepared in PBS and sensitized with the antigen. Sensitization was done with various dilutions of the antigen preparation (as in the HA test) and for varying periods (one, two, and three hours). Such sensitized cells were washed, resuspended, and then reacted with serum dilutions (as under the HA test) at $37^{\circ} \mathrm{C}$ for one and two hours. The presence or absence of haemagglutination was recorded.

(b) The formalinized red cells were subjected to tannic acid (BDH, Analar) treatment. A 1:20000 dilution of the tannic acid solution was mixed with an equal volume of a $2.5 \%$ red cell (formalinized) suspension and allowed to react at room temperature $\left(18-22^{\circ} \mathrm{C}\right)$ for one hour with gentle mixing. The tanned cells were washed several times with buffer. To a $1 \%$ tanned cell suspension an equal volume of antigen, optimally diluted for sensitization, was added and the mixture incubated at $37^{\circ} \mathrm{C}$ for one hour. These sensitized red cells were washed twice and suspended to a $2.5 \%$ concentration in PBS containing normal rabbit serum $(1: 200)$.

\section{Sensitization of fresh cells followed by formalinization and freeze drying}

Fresh sheep red cells (in Alsever's solution) were washed several times in PBS and then sensitized (see HA test) with the optimum dilution of the antigen suspension. An $8 \%$ suspension of sensitized, washed cells was prepared in PBS. These cells were treated with an equal volume of $3 \%$ neutral formalin (Analar grade) at $4^{\circ} \mathrm{C}$, with constant gentle stirring for 18 hours. The cells were then washed several times in PBS and suspended to the original concentration. These sensitized, formalinized red cells were mixed in equal volumes with a $30 \%$ sucrose solution (BDH, Analar), distributed in $1 \mathrm{ml}$ volumes in ampoules and freeze dried (Kyselova, Libich, and Sarbova, 1969-1970). Just before use the freeze-dried contents of each ampoule were reconstituted in $1 \mathrm{ml}$ of sterile distilled water and washed with 10 volumes of buffered saline to remove sucrose. From the sedimented cells a $2 \%$ suspension was prepared in buffered saline. These cells were used in the HA test.

\section{Preservation of sensitized red cells in $40 \%$} glycerol citrate

Sensitized sheep red cells (as above) washed twice in several volumes of buffered saline were preserved in $40 \%$ glycerol citrate according to the method of Gajewski and Greenwalt (1965). Such preserved cells were stored at $-20^{\circ} \mathrm{C}$ in small volumes. Before use the cells were deglycerolized at $37^{\circ} \mathrm{C}$ and suspended in PBS ( $p \mathrm{H} \mathrm{7.2)}$ or phosphate citrate buffer, $p \mathrm{H} 6.4$ (Merskey, Lalezari, and Johnson, 1969).

MICROSCOPIC AGgLUTINATION (MA) TEST A serial two-fold dilution of serum samples was made in PBS using a modified Takatsy microtitration set (Cooke Engineering Co, Alexandria, Va, USA). An equal volume $(0.025 \mathrm{ml})$ of live (7-dayold) culture of Leptospira was added to each serum dilution and the mixtures were incubated at $37^{\circ} \mathrm{C}$ for one hour. The endpoint (titre) was the highest dilution of serum showing less than $50 \%$ unagglutinated leptospires (World Health Organization, 1967). A $50 \%$ control was set up which helped in determination of the endpoint.

IMMUNODIFFUSION AND

IMMUNOELECTROPHORESIS

Immunodiffusion (Ouchterlony, 1949) was carried out in $1 \%$ ion agar in barbital buffer, $p \mathrm{H} \mathrm{7 \cdot 2.}$

Immunoelectrophoresis of serum samples was carried out in $1.5 \%$ ion agar in barbital buffer,

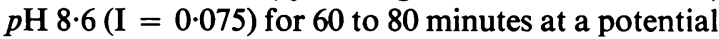
drop of $3 \mathrm{~V} / \mathrm{cm}$ (Chang and Faine, 1970).

\section{SERUM FRACTIONATION}

Serum samples were fractionated through a Sephadex G-200 column $(90 \times 3.2 \mathrm{~cm})$. The G-200 column was equilibrated with $0.05 \mathrm{M}$ tris buffer, $p \mathrm{H} 8.0$, in $1 \mathrm{M}$ sodium chloride solution. A $2-3 \mathrm{ml}$ volume of the serum sample to be fractionated was added to the column which was eluted with $0.05 \mathrm{M}$ tris buffer (as above). The effluent was passed through a Unicord II ultraviolet absorptiometer and the readings of absorption at $280 \mathrm{~nm}$ were plotted by a recorder. Column fractions of $5 \mathrm{ml}$ volume were collected in a LKB Radi Rac fraction collector. All buffer solutions contained $0.01 \%$ sodium azide and $0.01 \%$ thiomersal. The column was run at room temperature with a hydrostatic pressure of $40 \mathrm{~cm}$ and a flow rate of $12 \mathrm{ml}$ per hour. Every fraction of various peaks collected was tested for the presence of specific antibodies by serological tests.

\section{2-MERCAPTOETHANOL (2-ME) TREATMENT} OF SERUM

Human and rabbit serum samples were treated with 0.1M 2-ME by the method of Adler (1965) and the treated samples were dialysed against iodoacetamide. Control serum samples were processed similarly except that they were not treated with $2-\mathrm{ME}$. 
All the fractions of the first (19S) and the second (7s) protein peaks of the fractionated serum sample were tested for the presence of specific antibodies, and concentrated separately to the original serum volume in a Diaflo (R) apparatus (Amicon Corp, Lexington, Mass). The concentrate was again tested for the presence of specific antibodies. Aliquots from the first $(19 \mathrm{~S})$ protein peak concentrate were treated with 2-ME and the treated samples (together with controls) subsequently tested for the presence of specific antibodies.

\section{Results}

From 8 to 10 litres of Patoc 1 culture it was possible to obtain a yield of 18 to $22 \mathrm{mg}$ (dry weight) of the ethanol-precipitated antigen. The antigen was suspended in $2 \mathrm{ml}$ of PBS. The results of titration of this antigen suspension for the determination of the optimum sensitizing dilution are shown in Table $\mathrm{I}$. It was found that antigen dilutions of $1: 32$ and $1: 64$ gave a maximum haemagglutination titre $(1: 512)$ with the homologous immune serum sample. A $1: 32$ dilution of the antigen was thereafter used regularly to sensitize red cells for the HA test.

\section{CROSS-REACTIVITY OF SENSITIZED RED \\ CELLS WITH HOMOLOGOUS AND \\ HETEROLOGOUS ANTISERA}

Fresh sheep red cells sensitized with the ethanolprecipitated antigen showed a low-grade broad reactivity with various leptospiral antisera obtained from the Difco (Detroit, Michigan, USA) Laboratories (Table II). Antiserum against Autumnalis and Hyos showed very little reaction but the remaining Difco antisera showed 1:4-1:16 titre by the haemagglutination test. The sensitized red cells failed to react with the pooled normal rabbit serum. Three of these reactive Difco sera were treated with 2-ME. This resulted in complete loss of haemagglutinating

\begin{tabular}{ll}
\hline Antisera (Difco) & HA Titre \\
\hline Pomona & $1: 16$ \\
Canicola & $1: 16$ \\
Hyos & $1: 2 !$ \\
Icterohaemorrhagiae & $1: 16$ \\
Pyrogenes & $1: 8$ \\
Georgia (mini) & $1: 8$ \\
Grippotyphosa & $1: 16$ \\
Autumnalis & $1: 2:$ \\
Sejroe & $1: 4$ \\
Bataviae & $1: 16$ \\
Ballum & $1: 8$ \\
Normal rabbit serum (pooled) & $\mathrm{Nil}$ \\
Patoc 1 antiserum (rabbit 355) & $1: 512$ \\
\hline
\end{tabular}

Table II HA tests with homologous and heterologous abbit antisera using sensitized fresh sheep red cells \pm doubtful haemagglutination reactivity with only slight reduction in MA titre (Table III).

\begin{tabular}{|c|c|c|c|c|}
\hline \multirow[t]{2}{*}{ Antisera } & \multicolumn{2}{|c|}{$\begin{array}{l}\text { After 2-ME Treat- } \\
\text { ment }\end{array}$} & \multicolumn{2}{|c|}{ Untreated Control } \\
\hline & HA Titre Ti $^{1}$ & $M A$ Titre $^{2}$ & $H A$ Titre $^{1}$ & MA Titre \\
\hline Pomona & $\mathrm{Nil}$ & $1: 128$ & $1: 16$ & $\begin{array}{l}1: 256- \\
1: 512\end{array}$ \\
\hline Icterohaemorrhagiae & Nil & $1: 32$ & $1: 16$ & $\begin{array}{l}1: 64- \\
1: 128\end{array}$ \\
\hline Hyos & $\mathrm{Nil}$ & $\begin{array}{l}1: 128 \\
1: 256\end{array}$ & $1: 2 \pm$ & $1: 256$ \\
\hline
\end{tabular}

Table III Haemagglutination and microscopic agglutination reaction with 2-ME-treated rabbit sera

${ }^{1} \mathrm{HA}$ test was performed with Patoc I antigen

"MA test was performed with homologous antigen

REACTIVITY OF PRESERVED, SENSITIZED RED CELLS WITH RABBIT ANTISERA

1a The formalinized sheep red cells prepared by Daniel and Stavitsky's method (1964) showed no trace of haemolysis when washed before use for sensitization. The various dilutions (as in Table I) of the antigen suspension failed to sensitize sheep red cells even by varying the cell concentrations or by incubating for varying periods of time (one, two, and three hours). The failure of sensitization was established by recording non-reactivity (HA) of these red cells with homologous rabbit antiserum samples.

1b The formalinized sheep red cells could be sensitized with the optimum dilution $(1: 32)$ of the antigen after modifying these cells by tannic acid treatment. These formalinized, tanned, and sensitized red cells when tested against homologous and heterologous antiserum samples showed 1:2560 and 1:5120 titres respectively with two homologous rabbit antisera but no reactions with five different heterologous antiserum samples.

2 When the sensitized, freeze-dried red cells were reconstituted in water the cells went into suspension immediately. A $2 \%$ suspension of these cells was prepared and used in the HA test. Results presented in Table IV show that out of 10 various leptospiral antisera eight showed HA titres ranging from $1: 4$ to 1:16. Antiserum against Autumnalis and Hyos showed negative and poor $\mathrm{HA}$ titres respectively. Homologous serum samples obtained from three different rabbits showed $1: 256-1: 512$ titres by the HA test.

3 Sensitized sheep red cells preserved in $40 \%$ glycerol citrate (stored at $-20^{\circ} \mathrm{C}$ ) when deglycerolized showed significant haemolysis. These cells suspended either in PBS $(p H 7 \cdot 2)$ or in phosphate citrate buffer ( $p \mathrm{H} \mathrm{6.8)}$ showed further lysis and were regarded as unsuitable for use. 


\begin{tabular}{ll}
\hline Antisera (Difco) & HA Titre \\
\hline Pomona & $1: 16$ \\
Canicola & $1: 8-1: 16$ \\
Icterohaemorrhagiae & $1: 8-1: 16$ \\
Bataviae & $1: 16$ \\
Australis & $1: 4$ \\
Ballum & $1: 4$ \\
Sejroe & $1: 8$ \\
Autumnalis & $\mathrm{Nil}$ \\
Hyos & $1: 2 \pm$ \\
Georgia (mini) & $1: 8$ \\
Patoc 1 antisera & $1: 256-1: 512 \pm$ \\
Rabbit 355] & $1: 512$ \\
Rabbit 356] & $1: 512$ \\
\hline
\end{tabular}

Table IV Haemagglutination test on homologous and heterologous rabbit antisera using freeze-dried, sensitized (with Patoc 1 antigen) red cells

\pm doubtful haemagglutination

REACTIVITY OF HUMAN SERUM SAMPLES WITH FREEZE-DRIED（SENSITIZED） RED CELLS

Serum samples from 41 proven cases of leptospirosis occurring in Australia were tested for reactivity by the HA test using sensitized, freeze-dried sheep red cells. Results presented in Fig. 2 showed significant HA titres $(1: 32-1: 4098)$ in sera from human subjects infected with various serotypes of leptospires. Only two samples showed HA titres as low as $1: 16$ (Fig. 2).

An analysis was carried out to determine the correlation coefficient between the MA titres (as determined by the WHO Reference Laboratory in Brisbane) and the HA titres in the various sera representing infection with different serotypes. A significant correlation (at the 0.01 level) was found only in the case of all of the 23 human sera from hardjo infections.

A total of 19 sera from apparently healthy human subjects was tested by the HA test with the freeze-dried red cells. Among these sera, 10 gave negative HA, six showed a low titre of $1: 8$, and three samples reacted to a titre of $1: 16$. Most of these samples were subjected to the MA test against 18 different serotypes of leptospires but none showed any MA titre.

\section{REACTIVITY OF BOVINE SERA WITH SENSI-}

TIZED, FREEZE-DRIED RED CELLS

Twenty-eight cattle sera from proven cases of leptospirosis were tested by the HA test. The results presented in Fig. 2 show that the HA titres ranged from $1: 16$ to $1: 256$ with serum samples from cattle infected with various serotypes of leptospires. One sample showed an HA titre of 1:8 (Fig. 2). As with most of the human sera, the bovine samples also showed no definite correlation between the HA and MA titres.
ANTIBODY RESPONSE IN RABBITS INJECTED WITH ETHANOL-PRECIPITATED ANTIGEN Two rabbits were injected with the ethanol-precipitated antigen. Results showed that the HA titre appeared earlier than the microscopic agglutination titre (Fig. 1). The HA titre disappeared by the 30th day whereas the MA titre was still present. The MA titres were always higher than the HA titres.

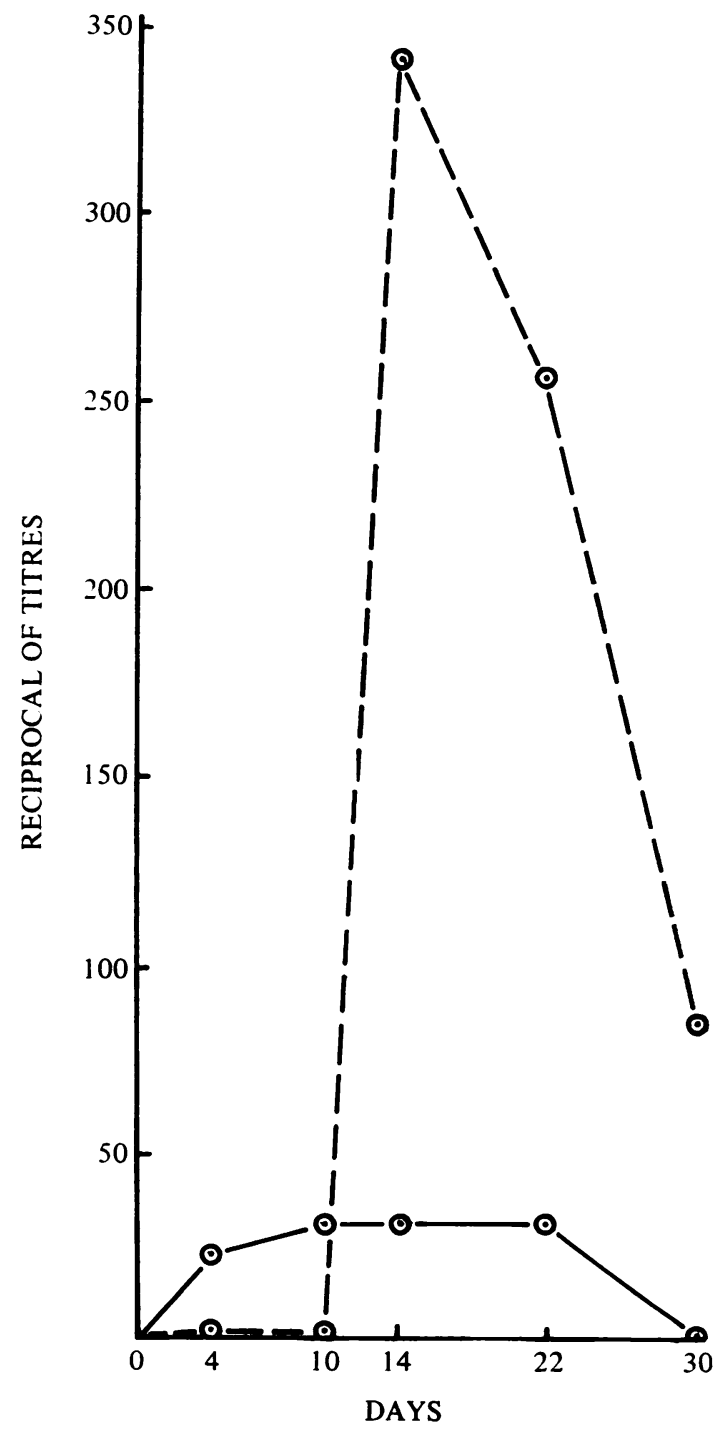

Fig. 1 Antibody response in rabbits injected with L. biflexa (Patoc 1) ethanol-precipitated antigen. Harmonic mean haemagglutination titre; .... . . . harmonic mean microscopic agglutination titre. 

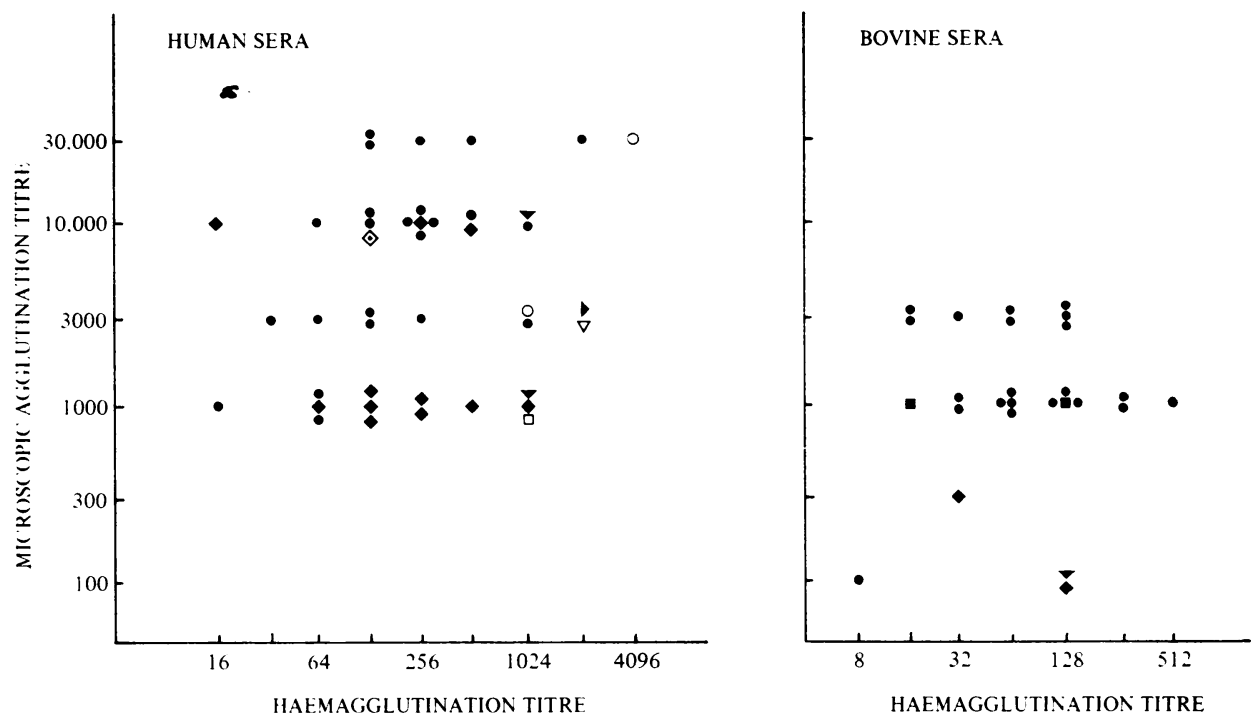

Fig. 2 Comparison of haemagglutination (genus-specific) and microscopic agglutination titres. $\checkmark$ pomona; $\nabla$ tarassovi; $\square$ bratislava; $\backslash$ broomi; $\diamond$ medanensis; $\bigcirc$ hardjo; O ictero; $\nabla$ canicola; $\square$ hyos.

IMMUNOGLOBULINS (OF HUMAN SERA) TAKING PART IN THE HAEMAGGLUTINATION TEST

Two serum samples from proven cases of human leptospirosis were fractionated separately through a Sephadex G-200 column. All the fractions of both the first (19S) and second (7S) protein peaks (Fig. 3) were assayed by the haemagglutination test. The results revealed the presence of haemagglutinating antibodies (Table V) only in the fractions of the first protein peak (19S). All the fractions of the 19S peak were pooled and concentrated to the original serum volume. The fractions of the $7 \mathrm{~S}$ peak were also treated in the same way. While the concentrated 19S peak material showed original serum haemagglutination titres (Table V) the 7S concentrate gave negative reactions. Reduction of the first peak (19S) concentrate with 2-mercaptoethanol demonstrated complete disappearance of haemagglutinating antibodies.

When the 19S peak concentrates of these two serum samples were tested separately by agar gel diffusion against goat antiserum to human IgM, a single precipitin line appeared in each case (Fig. 4).

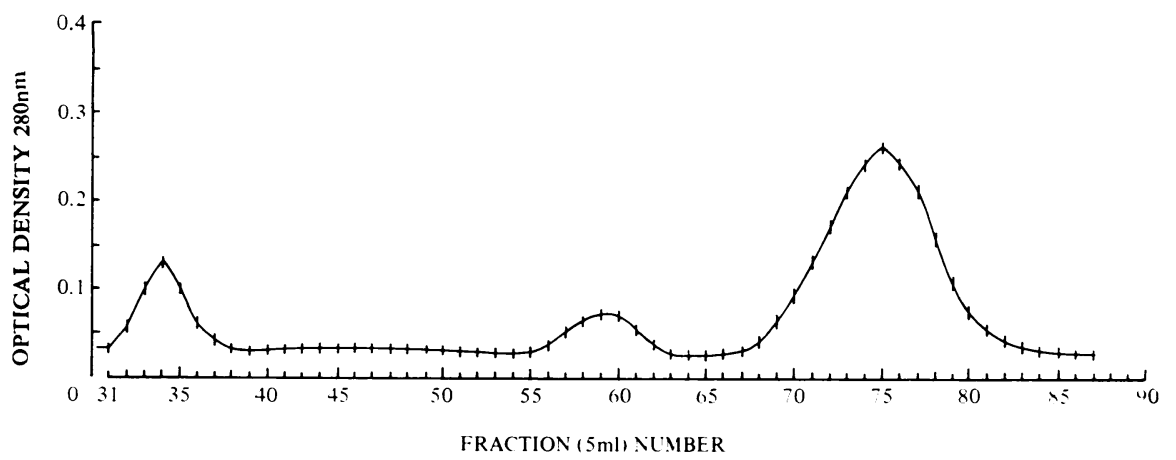

Fig. 3 Fractionation of human (leptospiral) antiserum through Sephadex G-200 column showing three protein peaks as plotted by a recorder. 


\begin{tabular}{|c|c|c|c|c|c|c|c|c|c|}
\hline \multirow[t]{2}{*}{$\begin{array}{l}\text { Serum No. } \\
\text { (or Rabbit No.) }\end{array}$} & \multirow[t]{2}{*}{ Species } & \multirow[t]{2}{*}{ HA Titre } & \multicolumn{2}{|c|}{$\begin{array}{l}\text { Antibody } \\
\text { Titres of } \\
\text { Fractions of } \\
\text { First Protein } \\
(19 S) \text { Peak }^{1}\end{array}$} & \multicolumn{2}{|c|}{$\begin{array}{l}\text { Antibody } \\
\text { Titres of Second } \\
\text { (7S) Protein } \\
\text { Peak } 1\end{array}$} & \multicolumn{2}{|c|}{$\begin{array}{l}\text { HA Titre of } \\
\text { Concentrated } \\
\text { First }(19 S) \\
\text { Protein Peak } 2\end{array}$} & \multirow[t]{2}{*}{$\begin{array}{l}\text { HA Titres of } \\
\text { Concentrated } \\
\text { Second }(7 S) \\
\text { Protein Peak }\end{array}$} \\
\hline & & & HA Titre & MA Titre & HA Titre & MA Titre & $\begin{array}{l}2-M E \\
\text { Treated }\end{array}$ & $\begin{array}{l}2-M E \\
\text { Untreated }\end{array}$ & \\
\hline $\begin{array}{l}3319 / 71 \\
3687 / 71 \\
355\end{array}$ & $\begin{array}{l}\text { Human } \\
\text { Human } \\
\text { Rabbit }\end{array}$ & $\begin{array}{l}1: 1024 \\
1: 64 \\
1: 256-1: 512 \\
\text { (MA } 1: 2048)\end{array}$ & $\begin{array}{l}1: 4-1: 64 \\
1: 2-1: 8 \\
1: 2-1: 8\end{array}$ & $\begin{array}{l}\text { N.D. } \\
\text { N.D. } \\
1: 2-1: 128\end{array}$ & $\begin{array}{l}\mathrm{Nil} \\
\mathrm{Nil} \\
\mathrm{Nil}\end{array}$ & $\begin{array}{l}\text { N.D. } \\
\text { N.D. } \\
1: 2-1: 8\end{array}$ & $\begin{array}{l}\mathrm{Nil} \\
\mathrm{Nil} \\
\mathrm{Nil}\end{array}$ & $\begin{array}{l}1: 1024 \\
1: 64 \\
1: 256\end{array}$ & $\begin{array}{l}\mathrm{Nil} \\
\mathrm{Nil} \\
\mathrm{Nil}\end{array}$ \\
\hline 442 (14 day) & Rabbit & $\begin{array}{l}1: 32 \\
\text { (MA 1:256) }\end{array}$ & $1: 2$ & $1: 2-1: 8$ & Nil & $1: 2-1: 8$ & Nil & $1: 32$ & Nil \\
\hline 442 (30 day) & Rabbit & Nil (MA $1: 64$ ) & Nil & $1: 2$ & Nil & $1: 8$ & N.D. & N.D. & N.D. \\
\hline
\end{tabular}

Table V Serological results of $19 S$ and 7 S protein peaks (from Sephadex G-200 column) of leptospiral sera

MA = Homologous microscopic agglutination titre

N.D. = Not done

${ }^{1}$ Dilution factors of serum samples after fractionation (G-200 column) were not considered.

${ }^{2}$ Concentrated to original serum volume

No reaction was recorded with one of the 2-ME treated serum samples. A faint line which appeared

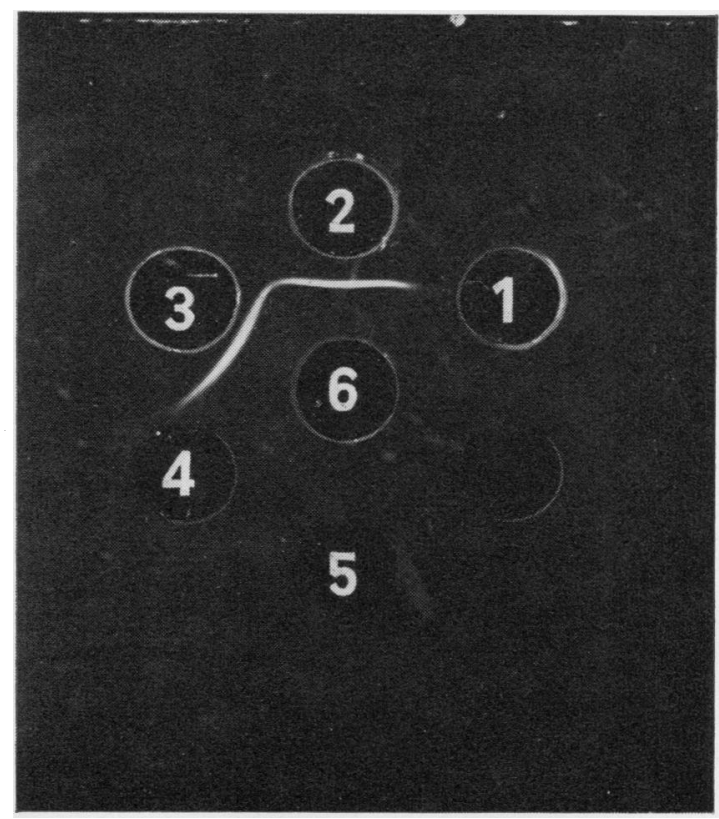

Fig. 4 Results of agar gel diffusion test with 2-ME treated and untreated $19 S$ peak concentrate against goat antiserum to human IgM.

1, 2ME treated $19 S$ peak concentrate (sample 3319)

2, 2ME untreated 19S peak concentrate (sample 3319)

3, $2 M E$ untreated 19S peak concentrate (sample 3687)

4, $2 M E$ treated $19 S$ peak concentrate (sample 3687)

5 , buffer control

6, goat antiserum to human IgM with the other serum sample treated with 2-ME failed to coincide with the adjacent IgM line (Fig. 4). It is possible that this effect was due to the presence of split heavy and light chains (Gray, 1970).

The 19S peak concentrate of the two human sera mentioned above failed to react with goat antiserum to human $\operatorname{IgA}$ when investigated by immunoelectrophoresis (Fig. 5). This finding proved the absence of IgA in the 19S peak concentrate of the two human sera.

IMMUNOGLOBULINS (OF RABBIT SERA) TAKING PART IN HAEMAGGLUTINATION AND MICROSCOPIC AGGLUTINATION TESTS

Serum samples collected on the 14th and 30th day after immunization from one of the two rabbits injected with the ethanol-precipitated antigen were fractionated through a Sephadex G-200 column. The separation of fractions was similar to that obtained with human serum (Fig. 3). Fractions belonging to the first protein peak (19S) of the 14th-day serum showed the presence of specific antibodies detectable by both haemagglutination and microscopic agglutination tests (Table V). On the other hand the second protein peak (7S) showed the presence of antibodies detectable only by the microscopic agglutination test. When all the fractions of the first (19S) protein peak were pooled and concentrated (to the original serum volume), the resulting concentrate showed the original serum HA titre $(1: 32)$. Treatment of this $19 \mathrm{~S}$ peak concentrate with $0 \cdot 1 \mathrm{M} 2-\mathrm{ME}$ resulted in the complete disappearance of $\mathrm{HA}$ and MA titres. The 30-day serum sample failed to react by the HA test while the MA test was positive to a titre of $1: 64$. Similar results were recorded with the anti-whole Patoc 1 serum when fractionated through the Sephadex G-200 column (Table V). 

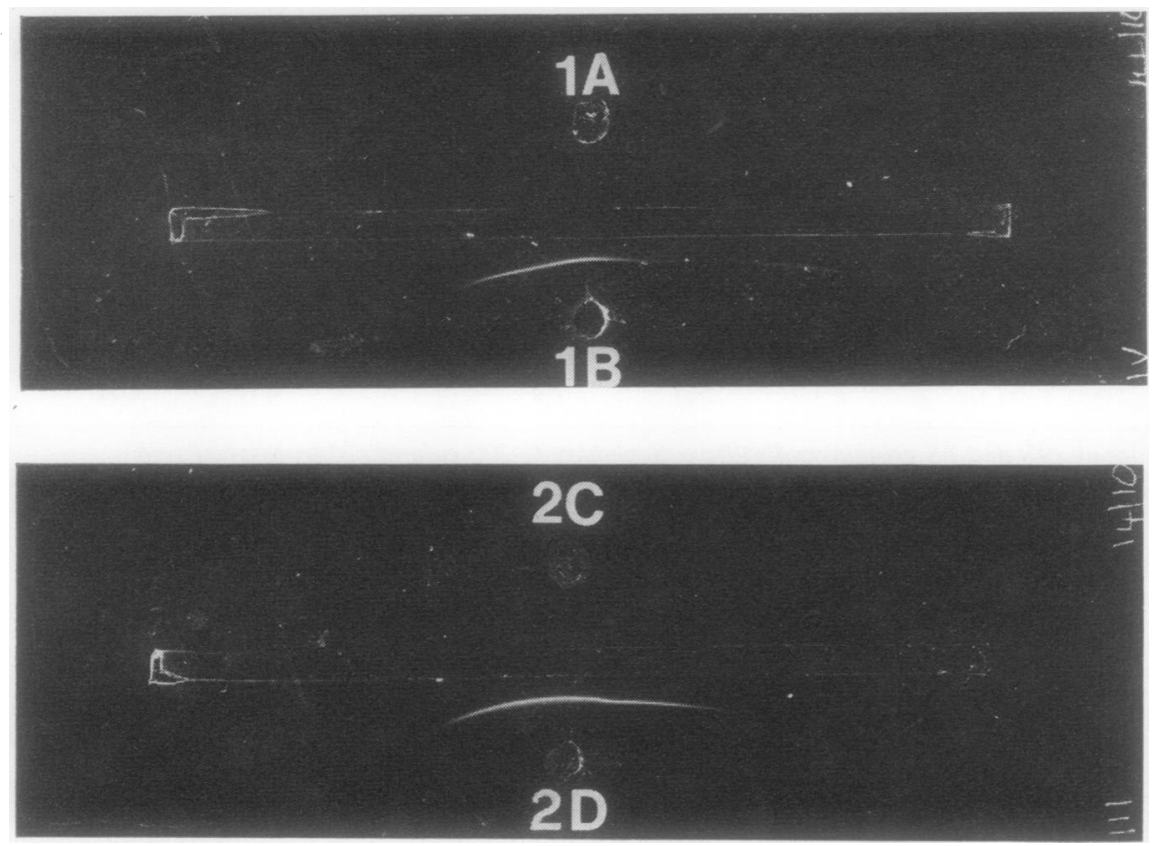

Fig. 5 Results of immunoelectrophoresis of 19 S peak concentrate (human leptospiral sera) with goat antiserum to human IgA.

$1 \mathrm{~A}, 19 \mathrm{~S}$ peak concentrate of sample 3687

$1 \mathrm{~B}$, normal human serum

2C, 19 S peak concentrate of sample 3319

2D, normal human serum

Central troughs in 1 and 2 goat antihuman $\operatorname{Ig} A$

Anode to the right and cathode to the left.

\section{Discussion}

The genus-specific reactivity of the strain Patoc 1 of the biflexa complex had been reported as early as 1958 (Combiescu, Sturdza, Sefer, and Radu). The Patoc strain has been found to provide a useful polyvalent antigen for the complement-fixation test (Sturdza and Elian, 1961; Turner, 1968). The genus-specific haemolytic test (HL) using an erythrocyte-sensitizing substance (ESS) of Chang and McComb (1954) from the CDC strain of biflexa complex was reported by Cox (1955) and by Cox, Alexander, and Murphy (1957). The HL test requires the use of complement and would be convenient to perform in laboratories carrying out routine complement-fixation tests. The HL test, however, lacks sensitivity and specificity when conducted with bovine and swine sera (World Health Organization, 1965) and for this purpose needs certain modifications.

In the present work the genus-specific (ethanolprecipitated) antigen of Chang and McComb (1954) was employed to sensitize sheep red cells and a method was evolved to freeze dry the red cells. The reason for the use of sheep red cells rather than human $\mathbf{O}$ cells was that the former are more easily available and less susceptible to haemolysis(Kyselová, Libich, and Serbová, 1969-1970).

The ethanol-precipitated antigen reported in this paper appears to contain at least two different types of red cell sensitizing substances. One of these components was possibly polysaccharide in nature as it could be coated onto unmodified, fresh sheep red cells (Neter, 1956 and 1970) while the other could be coated only onto tannic acid-modified red cells which indicated that it was possibly protein in nature (Neter, 1956 and 1970; Daniel and Stavitsky, 1964). The HA test carried out with the sensitized, fresh, unmodified red cells demonstrated genusspecific reactivity whilst the test with sensitized tanned cells showed serogroup specific reactions with various antisera. Further work on the isolation and characterization of these antigens is proceeding and this report will be published later.

In the present investigation, it was observed that 
the Difco antisera showed very low MA and HA titres. The evidence that the HA titres were abolished with 2-ME treatment suggest that antibodies responsible for haemagglutination viz, 19S (discussed later), were present but in low concentration only. On the other hand, with proven cases of leptospirosis good HA reactivity (Fig. 2) was noted with human and bovine serum samples. However, two human and one bovine serum sample showed low $(1: 8-1: 16)$ reactivity by the HA test. It is possible that these blood specimens were collected at a stage when specific IgM antibodies were in low concentration in the host. No history as to the stage of illness when these samples were collected was available. In human leptospirosis the 19S agglutinins have been known to appear earlier than the 7S agglutinins (Hartmann, Filitti-Wurmser, Jacquot-Armand, Mailloux, Hurez, and Fauvert, 1964; Lataste-Dorolle, Eyquem, and Buri, 1964; Pike, McBrayer, Schulze, and Chandler, 1965; Van Dalen, Seijen, and Gruber, 1967). In the present investigation an early appearance and disappearance of HA titres as compared with the microscopic agglutination titres was noted in the case of rabbits injected with the ethanol-precipitated antigen (Fig. 1). Turner (1968) too pointed out that the genus-specific tests may show positive reactions slightly earlier than the microscopic agglutination test.

It appears from the results that the use of sensitized (with genus-specific antigen), freeze-dried red cells in the HA test would be a useful tool for the screening of both human and bovine sera suspected of leptospirosis provided the sera were collected during the active stage of the infection. The freeze-dried cells would be easy to store and would also eliminate the standardization difficulties in sensitizing red cells. Another screening test that has been described and used successfully is the complement-fixation test, using a suitable complement-fixing antigen such as the one prepared by the Leptospirosis Reference Laboratory at the London School of Hygiene and Tropical Medicine (Turner, 1968). The HA test, however, would be particularly useful in laboratories which do not carry out complement-fixation tests as a routine. Sera found positive by the screening test should be subjected to further examination by the microscopic agglutination test.

The results of fractionation of rabbit and human sera, on the G-200 column, including (1) the effect of treatment of fractions with 2-ME; (2) agar gel diffusion (against goat antiserum to human IgM); (3) non-reactivity of 19S peak concentrates (human sera) with goat antiserum to human IgA in immunoelectrophoretic studies; and (4) the absence of HA activity in the 7S peak concentration support the view that the $19 \mathrm{~S}$ peak is IgM and that it is the latter which takes part in the haemagglutination test. The findings on rabbit antisera are in agreement with the observation of Palit and Faine (unpublished) that the 19S antibodies are responsible for the haemagglutination reaction whereas the microscopic agglutination test depends on the presence of both 7S and 19S immunoglobulins (Graves and Faine, 1970). However, the findings obtained in this study on human sera do not appear to have been reported before. Bovine sera have not yet been studied in this manner.

We are deeply indebted to Mr N. D. Stallman of the WHO Leptospira Reference Laboratory, Brisbane, for supplying Leptospira cultures and serum samples from human and bovine cases of leptospirosis and for conducting MA tests on several healthy serum samples.

Thanks are also due to Dr S. K. Sutherland and $\mathrm{Mr} \mathrm{H}$. C. Chandler for their help in various aspects of this work, to $\mathrm{Mr} \mathrm{W}$. Finger for statistical analysis, and to Miss B. Kaleja for her technical assistance.

\section{Referenzes}

Adler, F. L. (1965). Studies on mouse antibodies. II. Mercaptoethanol sensitive $7 \mathrm{~S}$ antibodies in mouse antisera to protein antigens. J. Immunol., 95, 39-47.

Alston, J. M., and Broom, J. C. (1958). Leptospirosis in Man and Animals, p. 303. Livingstone, Edinburgh.

Carpenter, P. L. (1965). Immunology and Serology, 2nd ed., p. 424. Saunders, Philadelphia and London.

Chang, A., and Faine, S. (1970). Electron microscopic evidence for reactions of axial filaments of Leptospira with IgM and IgG antibodies. Bull. Wld Hlth Org., 43, 571-577.

Chang, R. S. M., and McComb, D. E. (1954). Erythrocyte sensitizing substance (ESS) from five strains of leptospirae. Amer. J. trop. Med. Hyg., 3, 481-489.

Cox, C. D. (1955). Hemolysis of sheep erythrocytes sensitized with leptospiral extracts. Proc. Soc. exp. Biol. (N.Y.), 90, 610-615.

Cox, C. D., Alexander, A. D., and Murphy, L. C. (1957). Evaluation of the hemolytic test in the serodiagnosis of human leptospirosis. J. infect. Dis., 101, 210-218.

Combiescu, D., Sturdza, N., Sefer, M., and Radu, I. (1958). Rechirches sur les leptospiroses. Arch. roum. Path. exp. Microbiol., 17, 245-250.

Daniel, T. M., and Stavitsky, A. B. (1964). Passive hemagglutination in study of antigens and antibodies. Meth. Med. Res., 10, 152-157.

Ellinghausen, H. C., Jr., and McCullough, W. G. (1965). Nutrition of Leptospira pomona and growth of 13 other serotypes; fractionation of oleic albumin complex and a medium of bovine albumin and polysorbate 80 . Amer. J. vet. Res., 26, 45-51.

Faine, S. (1969). Acid-treated heated serum derivative for culture media for Leptospira. Appl. Microb., 17, 185.

Gajewski, M., and Greenwalt, T. J. (1965). The central file for rare donors and frozen blood program of the American Association of Blood Banks. Amer. J. med. Technol., 31, 175185.

Graves, S., and Faine, S. (1970). Antileptospiral agglutinins produced in rabbits. Bull. Wld Hlth Org., 43, 579-587.

Hartmann, L., Filitti-Wurmser, S., Jacquot-Armand, Y., Mailloux, M., Hurez, D., and Fauvert, R. (1964). Nature macromoléculaire d'un anticorps de la Leptospirose australis. Biochim. biophys. Acta (Amst.), 82, 249-259.

Kyselová, M., and Libich, M., and Srbová, H. (1969-1970). Titration of tetanus and diphtheria antibodies by means of hemagglutination test, using freeze dried sensitized sheep erythrocytes. Zeitschrift fur Immun.-Forsch., 139, 228-235.

Lataste-Dorolle, C., Eyquem, A., and Buri, J. F. (1964). Analyse immuno-électrophoretétique, en milieu gélosé, des protéines 
sériques dans les Leptospiroses. Ann. Inst. Pasteur, 106, 646650.

Merskey, C., Lalezari, P., and Johnson, A. J. (1969). A rapid, simple, sensitive method for measuring fibrinolytic split products in human serum. Proc. Soc. exp. Biol. (N.Y.), 131, 871-875.

Neter, E. (1956). Bacterial hemagglutination and hemolysis. Bact. Rev., 20, 166-188.

Neter E. (1970). Bacterial hemagglutination tests. In Gradwohl's Clinical Laboratory Methods and Diagnosis edited by S. Frankel, S. Reitman, and A. C. Sonnenwirth, 7th ed., vol. 2, pp. 1554-1556. Mosby, St. Louis.

Ouchterlony, O. (1949). Antigen-antibody reactions in gels. Acta path. microbiol. scand., 26, 507-515.

Palit, A., and Sharma, G. L. (1971). Comparison of microscopic agglutination, indirect haemagglutination and complement fixation tests in rabbit and buffalo-calf hyperimmune sera for detection of leptospiral antibodies. Brit. vet. J., 127, 154-162.

Pike, R. M., McBrayer, H. L., Schulze, M. L., and Chandler, C. H.
(1965). Chromatographic analysis and sulfhydryl sensitivity of antileptospira agglutinins in rabbit and human sera. Proc. Soc. exp. Biol. (N.Y.), 120, 786-789.

Sturdza, N., and Elian, M. (1961). Comparative study on different strains of L. biflexa as antigen for the complement fixation test in leptospirosis. Arch. roum. Path. exp. Microbiol., $20,33-41$.

Turner, L.H.(1968). Leptospirosis II. Trans. roy. Soc. trop. Med. Hyg., 62, 880-899.

Van Dalen, A., Seijen, H. G., and Gruber, H. (1967). Structural homologies in (Rabbit) immunoglobulins. J. molec. Biol., 23, 615-617.

World Health Organization (1965). Classification of leptospires and recent advances in leptospirosis. Bull. Wld Hlth Org., 32, 881891.

World Health Organization (1967). Current problems in leptospirosis research. Report of a W.H.O. Expert Group. Wld Hlth Org. techn. Rep. Ser., 380. 